\title{
Correction to: Power and Resource Allocation in Wireless Communication Network
}

\author{
Mohsin Nazir ${ }^{1}$ D $\cdot$ Aneeqa Sabah ${ }^{1} \cdot$ Sana Sarwar $^{1} \cdot$ Azeema Yaseen $^{2} \cdot$ Anca Jurcut $^{3}$ \\ Published online: 27 May 2021 \\ (c) The Author(s), under exclusive licence to Springer Science+Business Media, LLC, part of Springer Nature 2021
}

\section{Correction to: Wireless Personal Communications https://doi.org/10.1007/s11277-021-08419-x}

The 4th and 5th authors' affiliations were incorrect in the initial online publication. The original article has been corrected.

Publisher's Note Springer Nature remains neutral with regard to jurisdictional claims in published maps and institutional affiliations.

The original article can be found online at https://doi.org/10.1007/s11277-021-08419-x.

\section{Mohsin Nazir}

mohsinsage@gmail.com

1 Lahore College for Women University, Lahore, Pakistan

2 The National University of Ireland, Maynooth, Ireland

3 University College Dublin, Dublin, Ireland 